\title{
The Influence of Playing with Number Blocks on the Increase in Counting Ability in Class 4 Mental Retardation Children in SDLB/C Aditama Surabaya
}

\author{
Zuhrina Irma A'tiana ${ }^{1}$, Reliani'$^{2}$, Mundakir $^{3}$, Era Catur Prasetya ${ }^{4}$ \\ 1,3,3Fakultas Ilmu Kesehatan, Universitas Muhammadyah Surabaya \\ 4)Fakultas Kedokteran, Universitas Airlangga Surabaya
}

\begin{abstract}
Background: The number block is a media that Montessori created in 1909. This block media is made of a wooden square and consists of 10 blocks with red and blue colors. Each red and blue segment represents the sum of 1 block. According to Fridani in Kompas Daily (2010), the block game itself has several advantages, including that children can recognize mathematical concepts because by playing blocks, children get to know more concepts - less, the same and not the same, the concepts of numbers and numbers and science. Such as calculating, classification, gravity, and stabilization.
\end{abstract}

Objective: To determine the effect of number blocks on increasing numeracy skills in mentally disabled children

Method: The research design was a pre-experimental design with one group pre-test - a post-test design approach

Results: Before being given the intervention to play numeric blocks, most of the ten respondents (59\%) had the level of numeracy (analyzing number symbols, addition, and subtraction) in children with mental retardation, which was in the low category. Mental is in the good category for eight respondents (47\%), and five respondents $(29 \%)$ are included in the good category.

Conclusion: There is an effect of numeracy skills on children with mental retardation before and after the intervention to play number blocks.

Keywords: Number block; Counting ability; Mental retardation

Correspondence: wikreliayu@gmail.com

\section{PENDAHULUAN}

Retardasi mental merupakan suatu keadaan dimana seseoramg mengalami intelegensi yang kurang dari normal sejak masa perkembangan atau dalam masa anak-anak bahkan sejak anak baru dilahirkan. Mereka mengalami kesulitan dalam menyesuaikan diri atau beradaptasi dengan lingkungan disekitar, dan mengalami kesulitan untuk mengerti hal-hal yang abstrak, sulit, serta sesuatu hal yang disampaikan secara berbelit-belit. Anak dengan retardasi mental juga mengalami hambatan pada bidang akademik salah satunya berhitung (Apriyanto, 2012). Karateristik untuk seorang retardasi mental ialah dia dapat belajar keterampilan sosial dan pekerjaan yang cukup untuk mencari nafkah, tetapi memerlukan bimbingan dan bantuan 
bila mengalami stress sosial maupun stress ekonomi yang luar biasa (Prabowo, 2014).

Berdasarkan hasil studi pendahuluan yang dilakukan peneliti pada tanggal 18-19 Desember 2015 melalui wawancara langsung dengan kepala sekolah dan guru diketahui bahwa jumlah keseluruhan siswa kelas 4 ialah 17 siswa. Dari hasil wawancara dengan guru dan kepala sekolah tersebut juga diketahui bahwa kurikulum yang digunakan di sekolah tersebut ialah kurikulum luar biasa. Dimana kurikulum ini menuntut siswa kelas 4 untuk dapat menyebutkan bilangan 1 sampai dengan 100 sedangkan kemampuan berhitung mereka pada bilangan 1 sampai 15 serta operasi hitung mereka masih kurang. Selain itu metode pembelajaran yang digunakan di sekolah tersebut menggunakan metode ceramah 1 dimana metode ini menurut hasil observasi yang dilakukan peneliti pada siswa siwa di sekolah tersebut kurang efektif serta kurang menarik perhatian siswa. Tidak hanya itu, dari hasil observasi tersebut diketahui bahwa kemampuan berhitung siswa-siswa di sekolah tersebut masih kurang karena belum bisa mencapai target kemampuan berhitung yang terdapat dalam kurikulum di sekolah tersebut.

Berhitung merupakan susatu pelajaran yang harus dikuasai. Apabila anak mempunyai kemampuan berhitung yang kurang maka anak dapat memiliki hambatan dalam berfikir secara logis dan beradaptasi, serta anak tidak dapat menyesuaikan dengan lingkungan dalam keseharian yang memerlukan perhitungan. Permasalahan tentang kemampuan berhitung pada anak dapat diatasi dengan menerapkan aktivitas menarik dan efektif seperti kegiatan balok angka. Sebab bermain balok angka anak dapat bebas menggunakan imajinasi serta kemampuan untuk mengenal bentuk bilangan dan kemampuan menghubungkan benda dengan jumlah bilangannya. Permainan balok angka akan membuat peningkatan kualitas. Respon anak terhadap pembeljaran lebih antusisa, hal ini karena sambil bermain balok angka anak akan mampu mengenal angka (Cahyaningrum, 2013).

Dalam membrikan intervensi terkait dengan kemampuan berhitung untuk anak retardasi mental diperlukan suatu metode pembelajaran yang menyenamgkan, sehingga akan membuat anak merasa menikmati pemebelajaran seolah olah dia sedang bermain. salah satu bentuk permainan yang bisa dilakukan kepada anak ratardasi mental adalah permainan balok angka.

Balok angka merupakan media yang telah diciptakan oleh Montessori pada tahun 1909. Media balok ini terbuat dari sebuah kayu yang berbentuk persegi dan terdiri dari 10 unit balok dengan warna merah dan biru. Setiap segmen warna merah dan biru mewakili jumlah 1 balok (Agustini, 2011). Menurut Fridani dalam Harian Kompas (2010), permainan balok itu sendiri mempunyai beberapa kelebihan diantaranya adalah anak dapat mengenal konsep matematika karena dengan bermain balok anak-anak mengenal konsep lebih banyak - lebih sedikit, sama dan tidak sama, konsep angka dan bilangan serta sains, seperti menghitung, klasifikasi, gravitasi dan stabilisasi.

Menurut Essa (dalam Mayasari 2001) adapun tahapan-tahapan dalam menggunakan balok-balok angka untuk mengenalkan angka terhadap anak 
sebagai berikut: One-to-one correspondence (Korespondensi satu-satu). Pada tahapan ini anak menyebutkan satu balok dengan menunjuk balok yang berjumlah satu, menyebutkan dua balok dengan menunjuk balok yang berjumlah dua, dan seterusnya. Rote counting (Menghafal bilangan) merupakan kemampuan mengulang angka-angka (membilang) yang akan membantu pemahaman anak tentang arti dari sebuah angka. Rational counting (menghitung rasional) dimana anak secara akurat menempel sebuah nama angka untuk serangkaian objek yang dihitung, sehingga anak dapat mnegerti makna dari sebuah angka.

Penelitian tentang pengaruh balok angka untuk meningkatkan kemampuan berhitung sudah pernah diteliti oleh Vitri Purwanti tahun 2013 dimana hasilnya menunjukan bahwa telah terjadi peningkatan kemampuan berhitung pada siswa dengan menggunakan media balok angka. Responen dalam penelitian yang dilakukan Vitri Tabel 3.1 Desain penelitian pengaruh bermain balok angka tehadap peningkatan kemampuan berhitung pada anak retardasi mental kelas 4 di SDLB/C Aditama Surabaya.

\begin{tabular}{lccc}
\hline Subjek & Pra & Perlakuan & Post \\
\hline RM & O & I & OI \\
\hline
\end{tabular}

Keterangan :

$\begin{array}{ll}\mathrm{RM} & \text { : Anak retardasi mental } \\ \mathrm{O} & \text { : Observasi sebelum perlakuan }\end{array}$

\section{Populasi, Sampling, Sampel}

Menurut Sugiono (dalam Hidayat 2010) populasi merupakan seluruh objek dengan krateristik tertentu, bukan hanya objek atau subyek yang dipelajari namun seluruh karateristik atau sifat yang dimiliki oleh setiap objek atau subyek tersebut.
Purwanti tersebut ialah anak TK tanpa kebutuhan khusus. Sedangkan dalam penelitian ini peneliti mencoba untuk melakukan sebuah penelitian yang sama seperti penelitian yang dilkaukan oleh Vitri Purwanti tersebut tetapi responden dalam penelitian saya ini ialah anak dengan kebutuhan khusus yaitu anak dengan retardasi mental.

\section{METODE PENELITIAN}

\section{Desain Penelitian}

Desain penelitian menggunakan rancangan penelitian pre experimental design dengan pendekatan one group pre-test - post test design jenis pendekatan ini dilakukan dengan cara sebelum diberikan treatment/ perlakuan, variabel diobservasi/ diukur terlebih dahulu (pre-test) setelah dilakukan treatment/ perlakuan dan setelah treatment dilakukan pengukuran/ observasi (post test) (Hidayat, 2010).

\section{I $\quad$ : Intervensi \\ OI : Observasi setelah perlakuan}


Sampel merupakan suatu bagian dari populasi yang akan diteliti atau sebagian dari jumlah karateristik yang dimiliki oleh populasi. Tujuan ditentukan sampel adalah untuk mengerti karateristik suatu populasi, karena tidak dimungkinkannya peneliti melakukan penelitian di populasi, karena jumlah populasi yang sangat besar (Hidayat 2010). Sampel pada penelitian kali ini adalah siswa retardasi mental yang bersekolah di SLB-C Aditama Surabaya kelas 4 dengan kemampuan berhitung kurang yang berjumlah 17 siswa.

Sampling merupakan suatu proses untuk menyeleksi sampel yang akan digunakan dalam suatu penelitian dari populasi yang sudah ada, sehingga jumlah sampel akan mewakili dari keseluruhan populasi (Hidayat, 2010). Pada penelitian ini sampel diambil dengan cara Total Sampling yaitu teknik pengambilan sampel dimana jumlah sampel sama dengan jumlah populasi (Sugiyono, 2007).

\section{Variabel Penelitian}

Varibel merupakan suatu konsep yang dapat dibedakan menjadi dua bagian, yaitu kuantitatif dan kualitatif (Hidayat, 2014). Variabel independen pada penelitian ini adalah bermain balok angka. Variabel dependen adalah kemampuan berhitung sebagai variabel dependen.

\section{Lokasi dan Waktu Penelitian}

Penelitian ini dilakukan di SLB-C Aditama Surabaya dan dilaksanakan mulai tanggal 30 Mei 2016.

\section{Pengumpulan dan Analisa Data}

Cara pengumpulan data tersebut meliputi wawancara, observasi atau pengamatan, angket atau questionare (Hidayat, 2010). Instrumen yang digunakan peneliti adalah lembar observasi, serta balok angka yang dibuat sendiri oleh peneliti dengan bahan dasar kain flanel dan darkon. Penelitian dilakukan selama 1 bulan, untuk mendapatkan data kemampuan berhitung anak sebelum diberi intervensi, peneliti melakukan (pre test) dengan memberikan soal yang akan dikerjakan oleh anak tentang berhitung: konsep bilangan 1 sampai dengan 15, penjumlahan, dan pengurangan pre test dilakukan selama 2 hari. Intervensi bermain balok angka diberikan selama 3 minggu dan 2 kali pertemuan disetiap minggu. Minggu pertama permainan difungsikan untuk melatih kemampuan dalam mengenal konsep bilangan 1 sampai 15, minggu kedua permainan difungsikan untuk melatih kemampuan penjumlahan dan pada minggu ketiga difungsikan untuk melatih kemampuan pengurangan, dimana pada setiap pertemuan dilakukan dengan waktu 60 menit. Pada minggu keempat peneliti melakukan post test. Kemudian dibandingkan dengan nilai awal (pre test) untuk mengetahui pengaruh bermain balok angka terhadap peningkatan kemampuan berhitung responden.

Setiap jawaban yang telah ada pada lembar observasi pada kemampuan berhitung diberi kode masing-masing yaitu: kode angka " 0 " diberikan untuk jawaban yang salah, dan kode angka "1" 
diberikan untuk jawaban yang benar. Data yg terkumpul dilakukan skoring sebagai berikut: Angka 80\%-100\%: Baik, Angka 60\%-79\%: Cukup, dan $\leq 60 \%$ : Kurang

Data yang sudah terkumpul dianilisis menggunakan uji Wilcoxon Sign Rank Test yang merupakan uji komparasi dengan satu sampel berpasangan (dua pengamatan), yakni ingin dengan menggunakan Software Product and Service Solution 16.00; membandingkan dua pengamatan yang berasal dari satu sampel (Hidayat, 2011). Dengan tingkat kemaknaan $\alpha$ $\leq 0,05$ yang artinya jika hasil uji statistic menunjukkan 0,05 , maka ada pengaruh yang signifikan.

\section{HASIL PENELITIAN}

\section{Gambaran Lokasi Penelitian}

Penelitian ini dilakukan di salah satu sekolah luar biasa (SLB) yang ada di Surabaya yaitu SDLB-C Aditama Surabaya. Sekolah yang dikepalai oleh Eni Purwati, S.Pd. ini berdiri pada tanggal 5 Maret 1974. Sekolah ini berlokasi di Wisma Permai 102 Surabaya, Kelurahan Mulyorejo, Kecamatan Mulyorejo, Surabaya. Sekolah dengan NSS.830405600801 dan NPSN.20532443 yang sekarang terakreditasi B ini berada dibawah naungan Yayasan Kesehatan Jiwa Aditama yang dipimpin oleh Prof. dr. R. H. Moejiono Notosoedirjo, MPH. Sekolah ini memiliki 9 ruangan kelas yang terdiri dari 6 kelas untuk SD dan 3 kelas untuk SMP. Selain 9 ruang kelas, sekolah ini juga memiliki ruang kepala sekolah dan ruang guru, 4 kamar mandi, 1 mushola, serta lapangan upacara.

\section{Karateristik Demografi Responden}

\section{Usia}

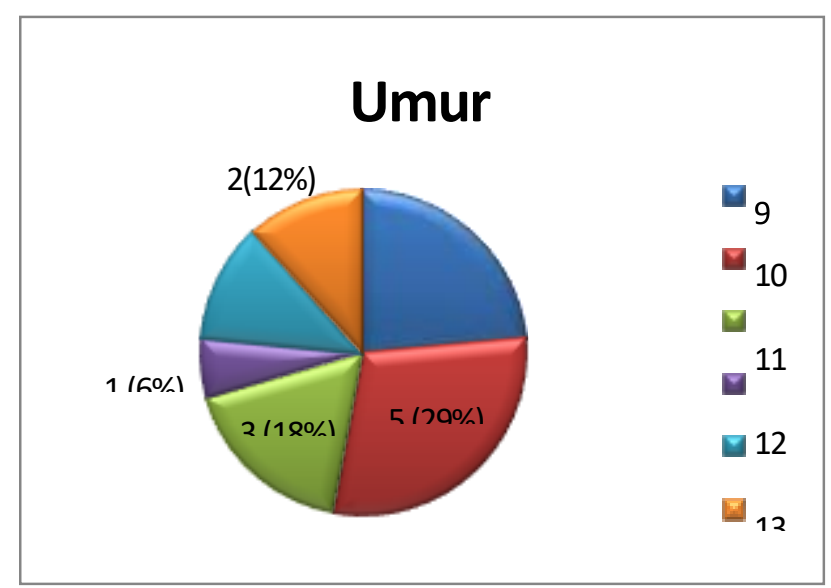

Gambar 4.1 Diagram Responden Berdasarkan Umur di SDLBC Aditama Surabaya Mei Tahun 2016

Berdasarkan Gambar 4.1 menunjukan bahwa sebagian besar responden berusia 10 tahun yaitu sebanyak 5 responden $(29 \%)$, dan sebagian kecil responden berusia 12 tahun yaitu sebanyak 1 responden (6\%). 


\section{Jenis Kelamin}

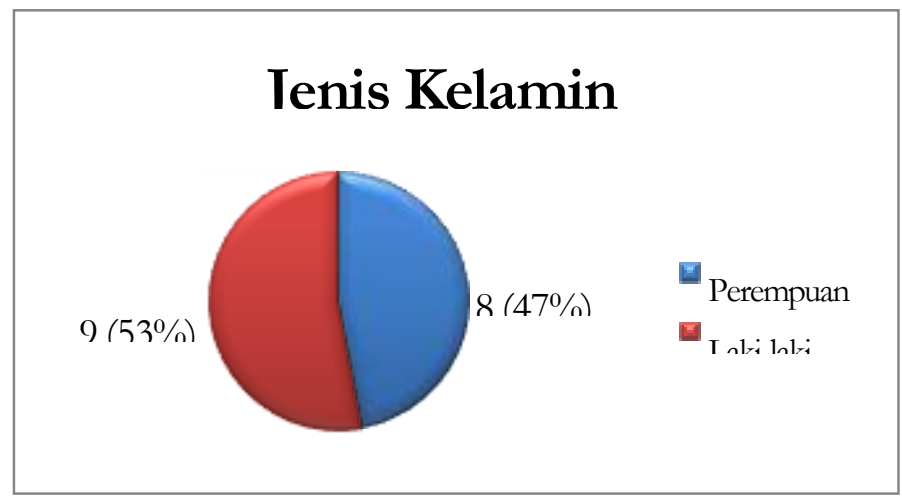

Gambar 4.2 Diagram Responden Berdasarkan Jenis Kelamin di SLBC Aditama Surabaya Mei Tahun 2016 Berdasarkan Gambar 4.2 menunjukan bahwa dan sebagian kecil responden berjenis kelamin sebagian besar responden berjenis kelamin perempuan yaitu sebanyak 8 responden $(47 \%)$. laki-laki yaitu sebanyak 9 responden (53\%),

\section{Kelas}

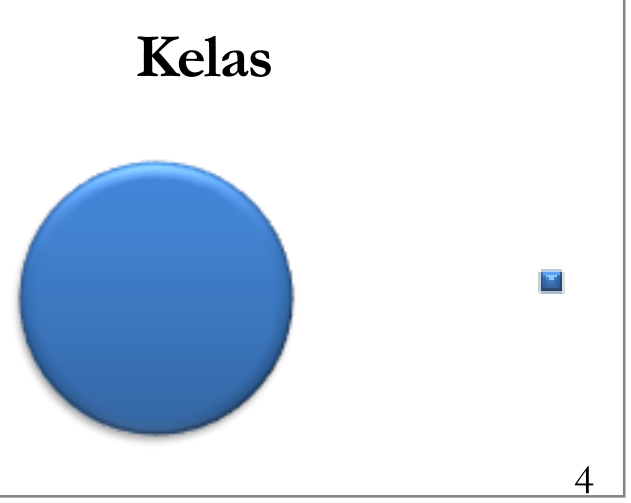

Gambar 4.3 Diagram Responden Berdasarkan Kelas di SDLBC Aditama Surabaya Mei Tahun 2016

Pada Gambar 4.3 diketahui bahwa semua 17 responden (100\%).

responden duduk di kelas 4 SD yaitu sebanyak

Tingkat Kemampuan Berhitung Pada Anak Retardasi Mental Sebelum Dilakukan Intervensi

\section{Bermain Balok Angka}

Berdasarkan Tabel 4.1 diatas menunjukkan bahwa hasil penelitian terhadap kemampuan berhitung responden sebelum dilakukan intervensi bermain balok angka dari total 17 responden diketahui bahwa sebagian besar kemampuan berhitung responden termasuk dalam kategori kurang yaitu sebanyak 10 responden (59\%). 
Tabel 4.1 Tingkat Kemampuan Berhitung Anak Retardasi Mental Sebelum Dilakukan Intervensi Bermain Balok Angka di SLBC Aditama Surabaya Mei Tahun 2016

\begin{tabular}{|l|c|c|}
\hline \multirow{2}{*}{ Tingkat Kemampuan Berhitung } & \multicolumn{2}{|c|}{$\begin{array}{c}\text { Tingkat Kemampuan Berhitung Anak Retardasi Mental } \\
\text { Sebelum Dilakukan Intervensi Bermain Balok Angka (PreTest) }\end{array}$} \\
\cline { 2 - 3 } & $\mathbf{N}$ & $\%$ \\
\hline Baik & - & - \\
\hline Cukup & 7 & $41 \%$ \\
\hline Kurang & 10 & $59 \%$ \\
\hline Jumlah & 17 & $100 \%$ \\
\hline
\end{tabular}

Tingkat Kemampuan Berhitung Pada Anak Retardasi Mental Sesudah Dilakukan Intervensi

\section{Bermain Balok Angka}

Tabel 4.2 Tingkat Kemampuan Berhitung Pada Anak Retardasi Mental Sesudah Dilakukan Intervensi Bermain Balok Angka di SDLBC Aditama Surabaya Mei Tahun 2016

\begin{tabular}{|l|c|c|}
\hline \multirow{2}{*}{ Tingkat Kemampuan Berhitung } & \multicolumn{2}{|c|}{$\begin{array}{c}\text { Tingkat Kemampuan Berhitung Anak Retardasi Mental } \\
\text { Sesudah Dilakukan Intervensi Bermain Balok Angka (PostTest) }\end{array}$} \\
\cline { 2 - 3 } & $\mathbf{N}$ & $\mathbf{\%}$ \\
\hline Baik & 5 & $29 \%$ \\
\hline Cukup & 8 & $47 \%$ \\
\hline Kurang & 4 & $24 \%$ \\
\hline Jumlah & 17 & $100 \%$ \\
\hline
\end{tabular}

Berdasarkan Tabel 4.2 diatas menunjukkan bahwa hasil penelitian terhadap kemampuan berhitung responden sesudah dilakukan intervensi bermain balok angka dari total 17 responden diketahui bahwa kemampuan berhitung responden yang termasuk dalam kategori baik yaitu sebanyak 5 responden $(29 \%)$, yang termasuk dalam kategori cukup yaitu 8 responden (47\%), dan yang termasuk dalam kategori kurang yaitu 4 responden (24\%)

\section{Hasil Tabulasi Tingkat Kemampuan Berhitung Pada Anak Retardasi Mental Sebelum Dan Sesudah Dilakukan Intervensi Bermain Balok Angka}

Tabel 4.3 Hasil Tabulasi Tingkat Kemampuan Berhitung Pada Anak Retardasi Mental Sebelum Dan Sesudah Dilakukan Intervensi Bermain Balok Angka di SLBC Aditama Surabaya Mei Tahun 2016

\begin{tabular}{|l|c|c|c|c|}
\hline \multirow{2}{*}{ Tingkat Kemandirian } & \multicolumn{2}{|c|}{ PreTest } & \multicolumn{2}{c|}{ PostTest } \\
\cline { 2 - 5 } & $\mathrm{N}$ & $\%$ & $\mathrm{~N}$ & $\%$ \\
\hline Baik & - & - & 5 & $29 \%$ \\
\hline Cukup & 7 & $41 \%$ & 8 & $47 \%$ \\
\hline Kurang & 10 & $59 \%$ & 4 & $24 \%$ \\
\hline Jumlah & 17 & $100 \%$ & 17 & $100 \%$ \\
\hline & Wilcoxon Sign Rank Test $p=0.001<=0,05$ \\
\hline
\end{tabular}


Berdasarkan Tabel 4.3 diatas menunjukkan bahwa hasil penelitian terhadap kemampuan berhitung responden sebelum dilakukan intervensi bermain balok angka dari total 17 responden diketahui bahwa sebagian besar kemampuan berhitung responden termasuk dalam kategori kurang yaitu sebanyak 10 responden (59\%), sedangkan sesudah dilakukan intervensi bermain balok angka sebagian besar kemampuan berhitung responden termasuk dalam kategori cukup yaitu sebanyak 8 responden (47\%).

Berdasarkan pengujian data menggunakan statistik Wilcoxon Sign Rank Test yang bertujuan untuk mengetahui perbedaan kemampuan berhitung sebelum dan sesudah dilakukan intervensi bermain balok angka didapatkan hasil dengan signifikansi $p=0.001$ dengan tingkat kemaknaan $\alpha<0,05$, sehingga $\mathrm{H} 0$ ditolak dan $\mathrm{H} 1$ diterima, artinya ada pengaruh bermain balok angka terhadap kemampuan berhitung anak retardasi mental kelas 4 SD.

\section{PEMBAHASAN}

Tingkat Kemampuan Berhitung Pada Anak Retardasi Mental Sebelum Dilakukan Intervensi Bermain Balok Angka

Berdasarkan penelitian yang dilakukan menunjukkan bahwa hasil penelitian terhadap kemampuan berhitung responden sebelum dilakukan intervensi bermain balok angka dari total 17 responden diketahui bahwa sebagian besar kemampuan berhitung responden termasuk dalam kategori kurang yaitu sebanyak
10 responden (59\%), dan sebagian kecil kemampuan berhitung responden termasuk dalam kategori cukup yaitu sebanyak 7 responden (41\%).

Maramis (2006) menyatakan bahwa pembelajaran terhadap anak retardasi mental dirasa lebih sulit dibandingkan dengan anak normal, karena perhatian mereka mudah sekali tealihkan dengan hal-hal lain saat pembelajaran ssedang berlansung. Oleh karena itu diperlukan sebuah metode pembelajaran yang dapat menarik perhatian serta memberikan sebuah rangsangan yang baik bagi panca indera anak retardasi mental, salah satunya yaitu dengan alat permainan yang dapat berbunyi, mempunyai warna yang menarik, dan semuanya harus konkrit yang artinya dapat dilihat. Bermain adalah suatu kegiatan yang dapat dilakukan dengan menggunakan atau tanpa menggunakan alat yang akan menghasilkan sebuah pengertian dan informasi, kesenangan maupun mengembangkan imajinasi pada setiap anak. Ketika anak bermain secara aktif atau pasif, akan banyak membantu untuk memahami jalan fikiran anak, selain itu juga akan meningkatkan keterampilan berkomunikasi (Sudono, 2000).

Berdasarkan uraian di atas, kemampuan berhitung sebelum dilakukan intervensi bermain balok angka yang termasuk dalam kategori cukup dan kurang disebabkan karena anak retardasi mental yang duduk di bangku kelas 4 SD ini diajarkan oleh guru-guru 
disekolah tentang perhitungan yang sesuai dengan kurikulum luar biasa yang digunakan di SDLB-C Aditama Surabaya dimana murid kelas 4 harus sudah bisa perhitungan 1 hingga 100. Tetapi pada kenyataannya anak-anak kelas 4 SD yang ada di SDLB-C Aditama Surabaya ini hanya memahami angka 1-15 itupun masih jauh jika dikatakan memahami, selain itu terkait perhitungan yaitu penjumlahan serta pengurangan angka 1-15 sama sekali belum mengerti sepenuhnya. Padahal dalam penelitian yang dilakukan oleh Eza Yusdial (2014) juga disebutkan bahwa anak retardasi mental kelas 2 SD saja seharusnya sudah mampu berhitung 1 hingga 20, hal ini tentu sangat memprihatinkan mengingat kelas $4 \mathrm{SD}$ belum mampu mencapai standart yang seharusnya sudah tercapai pada kelas 2 SD.

Kurangnya kemampuan berhitung anak retardasi mental ini juga karena kurangnya peran serta anggota keluarga khususnya dalam membimbing anak untuk belajar berhitung menggunakan media yang tepat dengan kondisi anak retardasi mental. Anggota keluarga khususnya orang tua hanya mengajari berhitung tanpa memikirkan apakah cara, media, atau metode mereka dalam mengajari anak dalam berhitung sudah tepat atau tidak. Selain itu pihak sekolah khususnya guru yang sudah diberi amanat maupun kepercayaan oleh orang tua untuk mendidik putra-putri mereka juga kurang maksimal dalam menggali potensi metode-metode tertentu untuk meningkatkan kemampuan berhitung anak retardasi mental.
Dimana merode yang digunakan guru di SLBC tersebut saat mengajar hanya menggunakan metode ceramah, dimana metode ceramah ini dianggap kurang efektif. Sehingga anak merasa bosan pada saat waktu pembelajaran berlangsung. Karena metode merupakan faktor penting dalam proses pembelajaran khususnya pembelajaran berhitung yang dapat mempengaruhi kemampuan berhitung pada anak retardasi mental.

\section{Tingkat Kemampuan Berhitung Pada Anak}

\section{Retardasi Mental Sesudah Dilakukan}

\section{Intervensi Bermain Balok Angka}

Berdasarkan penelitian yang dilakukan menunjukkan bahwa hasil penelitian terhadap kemampuan berhitung responden sesudah dilakukan intervensi bermain balok angka dari total 17 responden diketahui bahwa sebagian besar kemampuan berhitung responden termasuk dalam kategori cukup yaitu sebanyak 8 responden (47\%), dan sebagian kecil kemampuan berhitung responden termasuk dalam kategori kurang yaitu sebanyak 4 responden (24\%). Berdasarkan hal tersebut dapat diketahui bahwa terjadi peningkatan kemampuan berhitung anak retardasi mental yaitu sebanyak $76 \%$.

Menurut Fridani dalam Harian Kompas (2010), permainan balok itu sendiri mempunyai beberapa kelebihan diantaranya adalah anak dapat mengenal konsep matematika karena dengan bermain balok anak-anak mengenal konsep lebih banyak - lebih sedikit, sama dan tidak sama, konsep angka dan bilangan serta 
sains, seperti menghitung, klasifikasi, gravitasi dan stabilisasi.

Menurut Essa dalam Mayasari (2001) adapun tahapan-tahapan dalam menggunakan balokbalok angka dalam mengenalkan angka terhadap anak sebagai berikut: One-to-one correspondence (Korespondensi satu-satu). Pada tahapan ini anak akan menyebutkan satu balok dengan menunjuk balok yang berjumlah satu, menyebutkan dua balok dengan menunjuk balok yang berjumlah dua, dan seterusnya. Rote counting (Menghafal bilangan) merupakan kemampuan untuk mengulang setiap angka (membilang) yang dapat membantu pemahaman anak tentang arti dari sebuah angka. Rational counting (menghitung rasional) dimana anak secara akurat akan menempel sebuah angka untuk serangkaian objek atau gambar yang dihitung, sehingga anak dapat mengerti makna dari sebuah angka.

Berdasarkan uraian diatas kemampuan berhitung responden sesudah dilakukan intervensi bermain balok angka yang ada dalam kategori baik dan cukup meningkat hingga $76 \%$ menunjukkan bahwa cara atau metode belajar yang telah dikemas dalam bentuk permainan balok angka telah tersalurkan dengan optimal kepada anak retardasi mental. Hal tersebut dikarenakan balok angka yang digunakan peneliti dalam pembelajaran berhitung tersebut memiliki warna yang mencolok, bentuk yang unik, tekstur yang lembut dimana hal-hal tersebut membuat anak retardasi mental tertarik terhadap pelajaran berhitung yang diberikan. Selain itu balok angka yang digunakan untuk pembelajaran berhitung ini juga dapat digunakan sebagai media pembelajaran di rumah, karena balok angka ini mudah dibuat dan hanya terbuat dari kain flanel yang diisi dengan darkon, dan harga lebih murah dibandingkan dengan balok angka yang terbuat dari kayu.

Adanya kemampuan berhitung anak retardasi mental yang masih dalam kategori kurang disebabkan karena anak kurang aktif dalam berpartisipasi saat mengikuti permainan balok angka dengan teman-temannya yang lain. Selain itu, juga disebabkan karena beberapa anak-anak yang kemampuan berhitungnya masuk dalam kategori kurang tersebut kesehariannya cenderung menarik diri dari teman-teman maupun lingkungannya, sehingga anak-anak tersebut mengalami kesulitan dalam berbaur dengan temantemannya saat peneliti melakukan permainan balok angka.

\section{Pengaruh Intervensi Bermain Balok Angka}

\section{Pada Anak Retardasi Mental}

Perbandingan kemampuan berhitung responden sebelum dan sesudah dilakukan intervensi bermain balok angka terdapat peningkatan dari sebelum intervensi ke sesudah intervensi.

Peningkatan kemampuan berhitung responden sendiri dapat dilihat dari tabel 4.3. Pada tabel tersebut dapat diketahui bahwa sebagian besar kemampuan berhitung responden sebelum mendapatkan intervensi pada mulanya 
termasuk dalam kategori kurang yaitu sebanyak 10 responden, tetapi setelah mendapatkan intervensi sebagian besar kemampuan berhitung responden termasuk dalam kategori cukup yaitu sebanyak 8 responden, dan dalam kategori baik sebanyak 5 responden.

Hasil penelitian menunjukkan bahwa setelah diberikan intervensi selama 8 kali (2 kali dalam satu minggu) sebagian besar responden mengalami peningkatan kemampuan berhitung. Hal ini dapat dilihat dari hasil dari uji statistik Wilcoxon Signed Rank. Test yang digunakan untuk mengetahui perbandingan tingkat kemampuan berhitung responden yang telah diberikan intervensi bermain balok angka didapatkan hasil signifikan yang menunjukkan $\varrho=0,001<a=0,05$. Yangber arti bahwa $\mathrm{H} 0$ ditolak dan $\mathrm{H} 1$ diterima, artinya ada pengaruh bermain balok angka terhadap kemampuan berhitung anak retardasi mental kelas 4 SD.

Balok angka yang telah didesain oleh peneliti untuk anak retardasi mental ini telah membuat mereka tertarik untuk mengikuti pembelajaran berhitung. Hal tersebut sesuai dengan teori yang telah dijelaskan oleh (Cahyaninhrum, 2013) bahwa permasalahan pada anak yang mengalami gangguan kemampuan berhitung dapat diatasi dengan melakukan hal yang menarik salah satunya yaitu dengan bermain balok angka. Sebab dengan permainan balok angka ini anak dapat bebas untuk menggunakan imajinasi mereka serta mereka dapat mengenal bentuk bilangan. Pembelajaran dengan menggunakan balok angka ini akan membuat anak menjadi lebih antusias, karena mereka belajar sambil bermain. Penjelasan di atas menunjukkan bahwa permainan balok angka ini merupakan cara atau metode yang tepat untuk digunakan dalam meningkatkan kemampuan berhitung. Ini artinya permainan balok angka ini terbukti berrpengaruh dalam meningkatkan kemampuan berhitung anak retardasi mental

\section{SIMPULAN}

Sebelum diberikan intervensi bermain balok angka sebagian besar 10 responden (59\%) tingkat kemampuan berhitung (menganal lambang bilangan, penjumlahan, dan pengurangan) pada anak retardasi mental termasuk dalam kategori kurang, Sesudah diberikan intervensi bermain balok angka tingkat kemampuan berhitung pada anak retardasi mental termasuk dalam kategori cukup untuk 8 responden (47\%), dan 5 responden (29\%) termasuk dalam kategori baik, dan Ada pengaruh kemampuan berhitung pada anak retardasi mental sebelum dan sesudah dilakukan intervensi bermain balok angka.

\section{DAFTAR PUSTAKA}

Agustini, Sri. 2011. Penggunaan bermain balok angka susun untuk meningkatkan kemampuan kognitif anak kelompok A di TK Budi Rahayu Wonorejo Pasuruan. Skripsi tidak diterbitkan. Malang: PG. PAUD UNM.

Ahmad, Susanto. 2011. Perkembangan Anak Usia Dini. Jakarta: Kencana Prenada Media Group. Alwi, Hasan. 2003. Tata Bahasa Bahasa Indonesia. Jakarta: Balai Pustaka. Anggani, Sudono, 2000. 
Sumber Belajar dan Alat Permainan. Jakarta: Grasindo

Apriyanto, Nunung. 2012. Seluk Beluk Tunagrahita \& Strategi Pembelajarannya. Jogjakarta: Javalitera

Arikunto, S. 2006. Prosedur Penelitian: Suatu Kegiatan Pendekatan Praktik. Jakarta: Rineka Cipta

Cahyaningrum, Apriyana. 2013. Meningkatkan Kemampuan Berhitung Melalui Media Balok Pada Anak Kelompok B Di Tk Guworejo 2 Karang Malang Kabupaten Sragen Tahun Ajaran 2013 / 2014. Skripsi Universitas Muhammadiyah Surakarta. Dipublikasikan.

Donna, L. Wong. 2008. Buku ajar keperawatan pediatrik. Jakarta: EGC.

Dwinda, R. Octa, dkk. (2014). Buku Ajar Asuhan Kebidanan Neonatus, Bayi/Balita dan Anak Prasekolah Untuk Para Bidan. Yogyakarta : Deepublish.

Fatkhurohmah. 2010. 'Peningkatan Kemampuan Berhitung Bilangan Bulat Melalui Model Pembelajapran Kooperatif Pada Siswa Kelas IV A SD Muhammadiyah Wonorejo Polokarto Sukoharjo Tahun Pelajaran 2009/2010”. Skripsi, Surakarta.

Hidayat, A. A. A. 2005. Pengantar Ilmu Keperawatan Anak 1. Jakarta: Salemba Medika. Hidayat, A. A. A. 2010. Metode Penelitian Kesehatan. Surabaya : Health Books Publishing Hidayat, A. A. A. 2014. Metode Penelitian Keperawatan dan Teknis Analisis Data. Jakarta: Salemba Medika
Hidayati, Ratna. 2010. Dasar-Dasar Membaca, Menulis dan Berhitung. Jakarta : Gramedia Pustaka Utama.

http://health.kompas.com/read/2010/08/13/11 453469/keuntungan.belajar.bermain. balok.untuk.si.batita

Lumbantobing, SM. 2006. Anak dengan Mental Terbelakang. Jakarta: Balai Penerbit FKUI.

Mayasari, Kartika. 2012. Pengaruh Penggunaan Balok-Balok Angka Terhadap Kemampuanmengenal Lambang Bilangan Pada Anak Kelompok A Di TK Aisyiyah Bustanul Athfal 7 Padang Bandung Dukun Gresik. Surabaya : PG. PAUD Universitas Surabaya.

Montolalu, B.E.F, dkk. 2005. Bermain dan Permainan Anak. Jakarta: Universitas Terbuka. Muhith, Abdul. 2015. Pendidikan Keperawatan Jiwa Teori dan Aplikasi. Yogyakarta: Andi Offset

Mutiah, D. 2010. Psikologi Bermain Anak Usia Dini. Jakarta: Kencana.

Nursalam. 2008. Konsep Dan Penerapan Metodologi Penelitian Ilmu Keperawatan Edisi 2. Jakarta : Salemba Medika

Nursalam. 2013. Metodologi Penelitian Ilmu Keperawatan: Pendekatan Praktis Edisi 3. Jakarta: Salemba Medika

Prabowo, E. 2014. Konsep dan Aplikasi Asuhan Keperawatan Jiwa. Jakarta: Nuha Medika Siregar, Eveline dan Nara, Hartini. 2010. Teori Belajar dan Pembelajaran. Bogor: Ghalia Indonesia 
Soetjiningsih dan IG. N. Gde Ranuh. 2013. Edisi

2: Tumbuh Kembang Anak. Jakarta : EGC

Soetiiningsih. 2005. Edisi Revisi : Tumbuh Kembang Anak. Jakarta: EGC.

Uswatun, 2012. Pengaruh Aktivitas Bermain Peran Dengan Hand Puppet Terhadap Kemandirian Dalam Pemenuhan Activity Daily Living (AdI) Pada Anak Retardasi Mental. Skripsi, FIK Universitas Muhammadiyah Surabaya.

Wiksanti, Esthy S.S. 2014. Mengupas Therapy Bagi Para Tuna Grahita: Retardasi Mental Sampai Lambat Belajar. Jogjakrta: Redaksi Maxima 